\title{
Endothelialization of Intravascular Stents
}

\author{
W.J. VAN DER GIESSEN, M.D.,* P.W. SERRUYS, M.D.,* PH.D., W.J. VISSER,** \\ P.D. VERDOUW, PH.D.,* W.P. VAN SCHALKWIJK, ${ }^{* * *}$ and J.F. JONGKIND, PH.D.** \\ From the Department of Cardiology, ${ }^{*}$ Thoraxcenter; Department of Cellbiology, ${ }^{* *}$ and Laboratory for Experimental Surgery, ${ }^{* * *}$ \\ Erasmus University, Rotterdam, The Netherlands
}

Wide clinical application of intravascular stenting devices is currently limited by occlusion or intraluminal narrowing caused by thrombosis and neointimal thickening in a considerable percentage of implantations. We studied the possibility of seeding one of the currently availiable stents, a stainless steel, self-expandable wire-mesh, with endothelial cells in vitro. Endothelial cells, derived from human umbilical cord veins, could be suc- cessfully attached to stent flaments. In vivo stent implantations in porcine femoral arteries showed complete covering of stent wires by endothelium after 1 week. We conclude that coating of stents with autologous endothelial cells prior to implantation might protect against early thrombosis during the period in which a neointima is formed. (J Interven Cardiol 1988:1:2)

that thrombosis still occurs in $20 \%-30 \%$ of the stents, in particular during the first 14 days after implantation. ${ }^{6,7}$ This may be related to the lack of a protective endothelial covering. Thrombosis occurs in these animals between 2 weeks and 3 months after implantation. Effective measures should be taken during the period between implantation and neointimal covering to prevent the incidence of thrombosis. In the present study we show that seeding stents with endothelial cells may be such a measure.

\section{Materials and Methods} evaluation..$^{2-6}$ Studies of peripheral and coronary arteries in sheep and dogs have, however, shown

Address for reprints: P.W. Serruys, M.D., Ph.D., Department of
Cardiology, Thoraxcenter, Erasmus University, Rotterdam,
P.0, Box 1738, 3000 DR Rotterdam, The Netherlands.

Submitted for publication February 1, 1988; accepted May 17, 1988 . yielded several stents for experimental and clinical

\section{Introduction}

Invasive therapy for atherosclerotic vascular disease has gradually shifted from surgery to a minal stenting with vascular endoprostheses was already attempted in the early days of balloon ancomplications and the prevention of restenosis. ${ }^{1}$ Narrowing of the stented segment caused by vices even in the larger (peripheral) arteries. Changes in design, the use of other metal alloys, and miniaturization of the endoprostheses now ( 
min at $125 \mathrm{~g}$, the cell pellet was resuspended in Medion M199 (Flow Laboratories Ltd, Irvine, Scotland) supplemented with serum and growth factors and cultured in a flask coated with fibronectine $\left(10 \mu \mathrm{g} / \mathrm{cm}^{2}\right)$ for 2 days. ${ }^{8,9}$

Description of the Stent. The stent used (Wallstent $^{\mathrm{R}}$, Medinvent SA, Lausanne, Switzerland) was a stainless-steel, open-weave wire-mesh (Fig. 1). The prosthesis is self-expanding and its elastic properties are such that its diameter can be substantially reduced by elongation. It can thus be constrained on a small-diameter delivery catheter, which consists of two coaxial catheters, the proximal regions of which are joined by an invaginated rolling membrane, which effectively retains the prosthesis. Withdrawal of the outer catheter rolls back the membrane progressively, thus releasing the stent, which tends to return to its orginal diameter, thereby anchoring itself against the arterial wall. The unconstrained diameter of the stent used in this study was $3.5 \mathrm{~mm}$ and the length $15 \mathrm{~mm}$.

Coating the Stents with Endothelium. The unconstrained stents were incubated with fibronectine $(100 \mu \mathrm{g} / \mathrm{mL})$ for $15 \mathrm{~min}$ at $37^{\circ} \mathrm{C}$ for support of endothelial coverage. Endothelial cell suspensions (derived as above) were brought together with the stent in a small siliconized glass tube and rotated ( $2 \mathrm{rpm}$ ) for 2 hours at $37^{\circ} \mathrm{C}$. Subsequently, the stent with cells were transferred to a petri dish, covered with medium and cultured overnight. For the coating of $1 \mathrm{~cm}$ stent (diameter $3.5 \mathrm{~mm}$ ) about 50,000 endothelial cells were used. The cells on the stent were stained with the vital DNA-stain Hoechst 33342 (Hoechst AG, Frankfort, FRG) (10 $\mathrm{uM} ; 1$ hour; $37^{\circ} \mathrm{C}$ ) or with the vital dye fluorescence diacetate (Serva, Heidelberg, FRG) (0.1 $\left.\mu \mathrm{g} / \mathrm{mL}, 10 \mathrm{~min} ; 37^{\circ} \mathrm{C}\right)$. Other stents were fixed with buffered glutaraldehyde (3\%) and stained

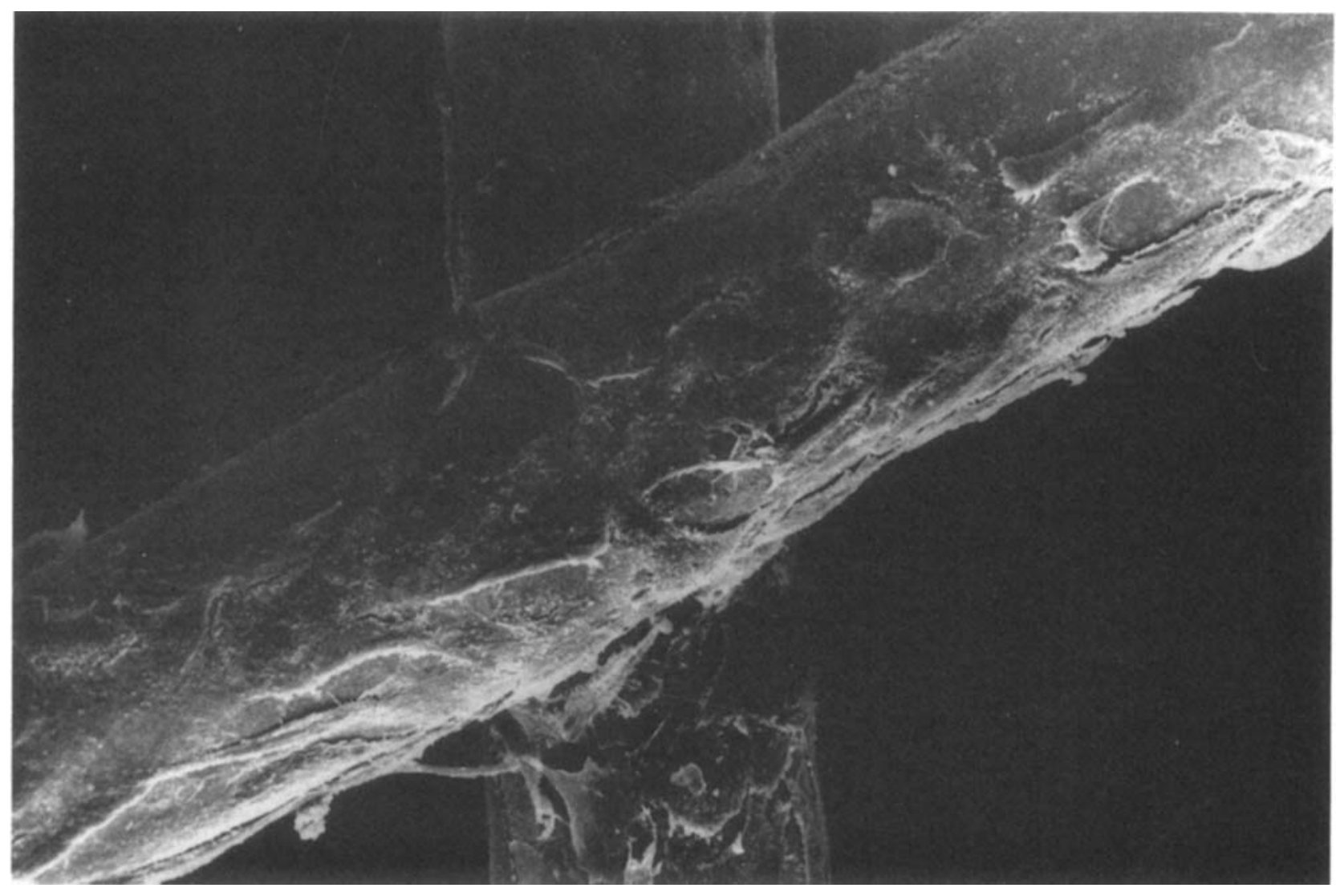

Figure 1. Scanning electron microscopic picture (magnification 550X) of stent wires seeded in vitro with cultured endothelial cells derived from umbilical cord veins. The flattened cells are in close contact. 


\section{ENDOTHELIALIZATION OF INTRAVASCULAR STENTS}

with the nuclear stain propidium iodide (Sigma, St Louis, MO, USA) $(10 \mu \mathrm{g} / \mathrm{mL})$. The cell-covered stents were observed with a fluorescence microscope with epi-illumination.

Coating the Stents Mounted on the Delivery Catheter. First the fibronectine solution and then the endothelial cell suspension was drained by applying a minimal suction at the central catheter of the stent-loaded delivery system. After sealing the tip of the stent-delivery catheter by a sterile glove covered finger the suspension was advanced through the pores of the central catheter until it had replaced the air around the stent filaments. Then the mounted stent was incubated overnight. The next day the stent was released from the catheter and placed in fluorescent dye (propidium io- dide, $10 \mu \mathrm{g} / \mathrm{mL}$ ) after fixation in phosphate buffered 3\% glutaraldehyde.

In Vivo Endothelialization of Stents. In 6 young Yorkshire swine $(18-25 \mathrm{~kg})$ a total number of 18 stents were implanted. After sedation with $500 \mathrm{mg}$ of ketamine hydrochloride (Aescoket, ${ }^{\mathrm{R}}$ Aesculaap BV, Boxtel, Holland) the animals were connected to a respirator for artificial ventilation with a mixture of oxygen and nitrous oxide, after endotracheal intubation. Anesthesia was maintained with 1-4 vol\% enflurane (Ethrane, ${ }^{\mathrm{R}}$ Abbott BV, Amstelveen, Holland) while pancuronium bromide (Pavulon, ${ }^{\mathrm{R}}$ Organon, Oss, Holland) was used as a muscle relaxant.

An $8 \mathrm{~F}$ introduction sheath was placed via the left carotid artery in the descending aorta. After

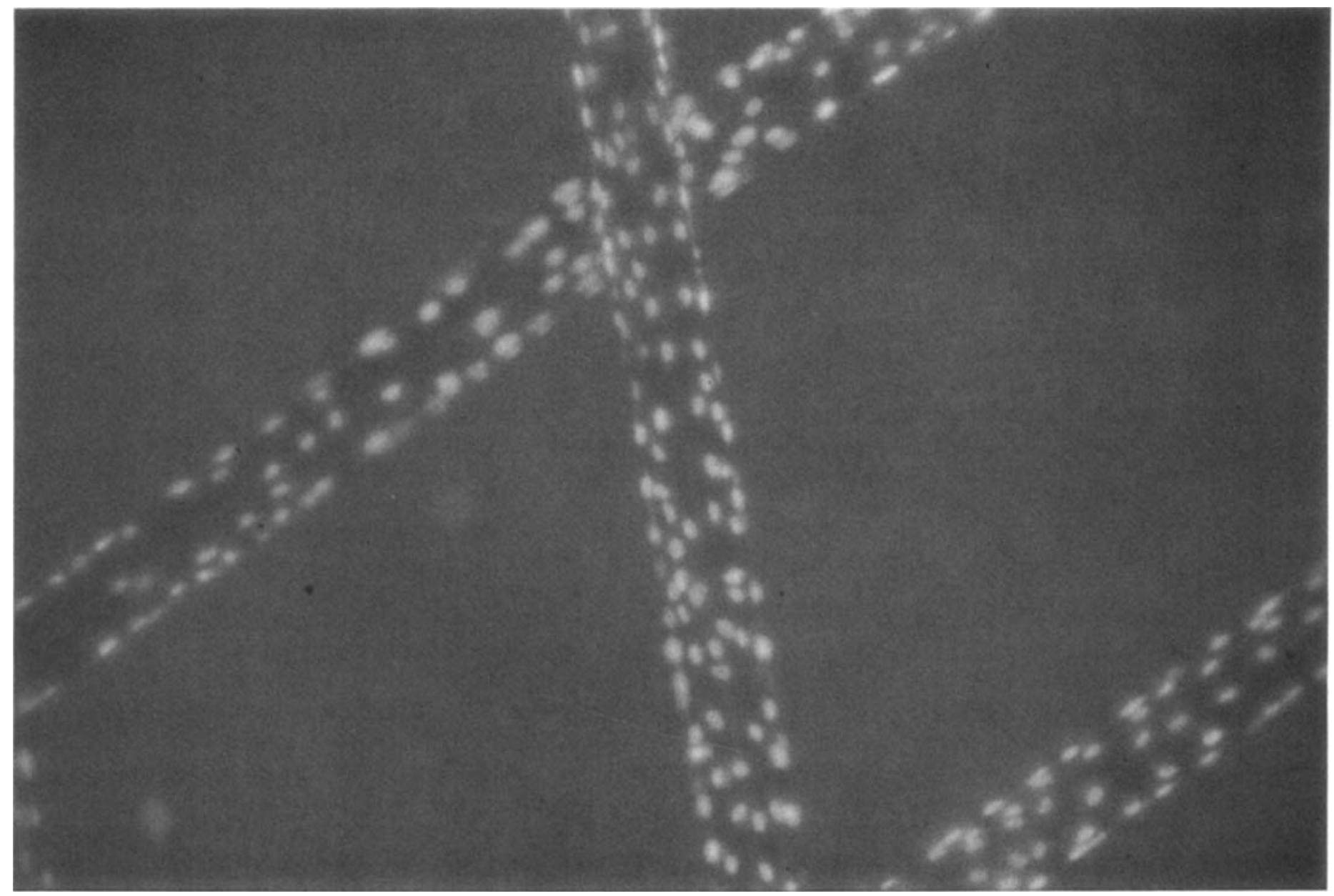

Figure 2. Fluorescence microscopy of stent wires coated with endothelial cells stained with the vital DNA stain Hoechst 33342 . The nuclei of the umbilical cord vein derived cells are uniformly distributed and abundant on the metal alloy filaments (magnification $200 \times$ ). 


\section{VAN DER GIESSEN, ET AL.}

intravenous administration of $5,000 \mathrm{IU}$ heparin and $100 \mathrm{mg}$ aspirin (Asṕegic. ${ }^{\mathrm{R}}$ Lorex, Weesp, Holland), an $8 \mathrm{~F}$ guiding catheter was advanced to the aorto-iliac bifurcation.

After baseline angiography of both femoral arteries a $300 \mathrm{~cm}, 0.014$ inch long guidewire was placed in the left femoral artery. Over the guide- wire an angioplasty balloon catheter (balloon size $3.5 \mathrm{~mm}$ ) was advanced. From the angiograms, and using the diameter of the guide catheter as a reference, a segment of the left femoral artery was chosen with a diameter of $3.0 \mathrm{~mm}$. At that point the angioplasty balloon was inflated twice for $60 \mathrm{sec}$ and $10 \mathrm{Atm}$ inflation pressure. Then the angio-

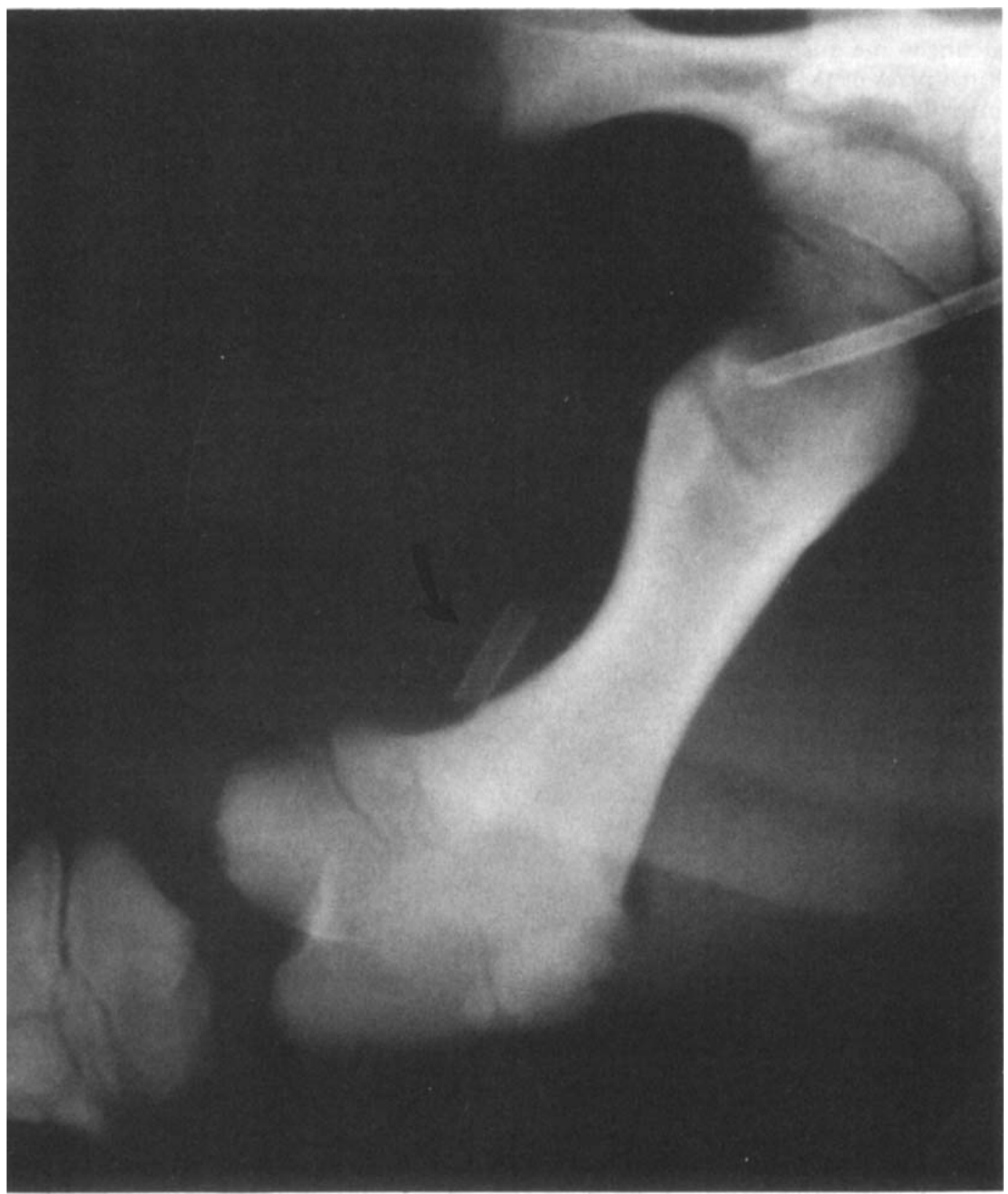

Figure 3A. X-ray of the stent (arrow) unplanted in the left femoral artery. 


\section{ENDOTHELIALIZATION OF INTRAVASCULAR STENTS}

plasty catheter was withdrawn, and angiography was repeated. The stent constrained delivery catheter, with an endoprosthesis mounted on its tip was positioned over the long guidewire at the dilated arterial segment. After the stent was released, catheters and guidewire were withdrawn to the aortic bifurcation, and repeat angiography was performed. The same procedure was followed for placement of a stent in the right (contralateral) femoral artery, except that at this site angioplasty was not performed. The catheters were removed, and the animals allowed to recover.

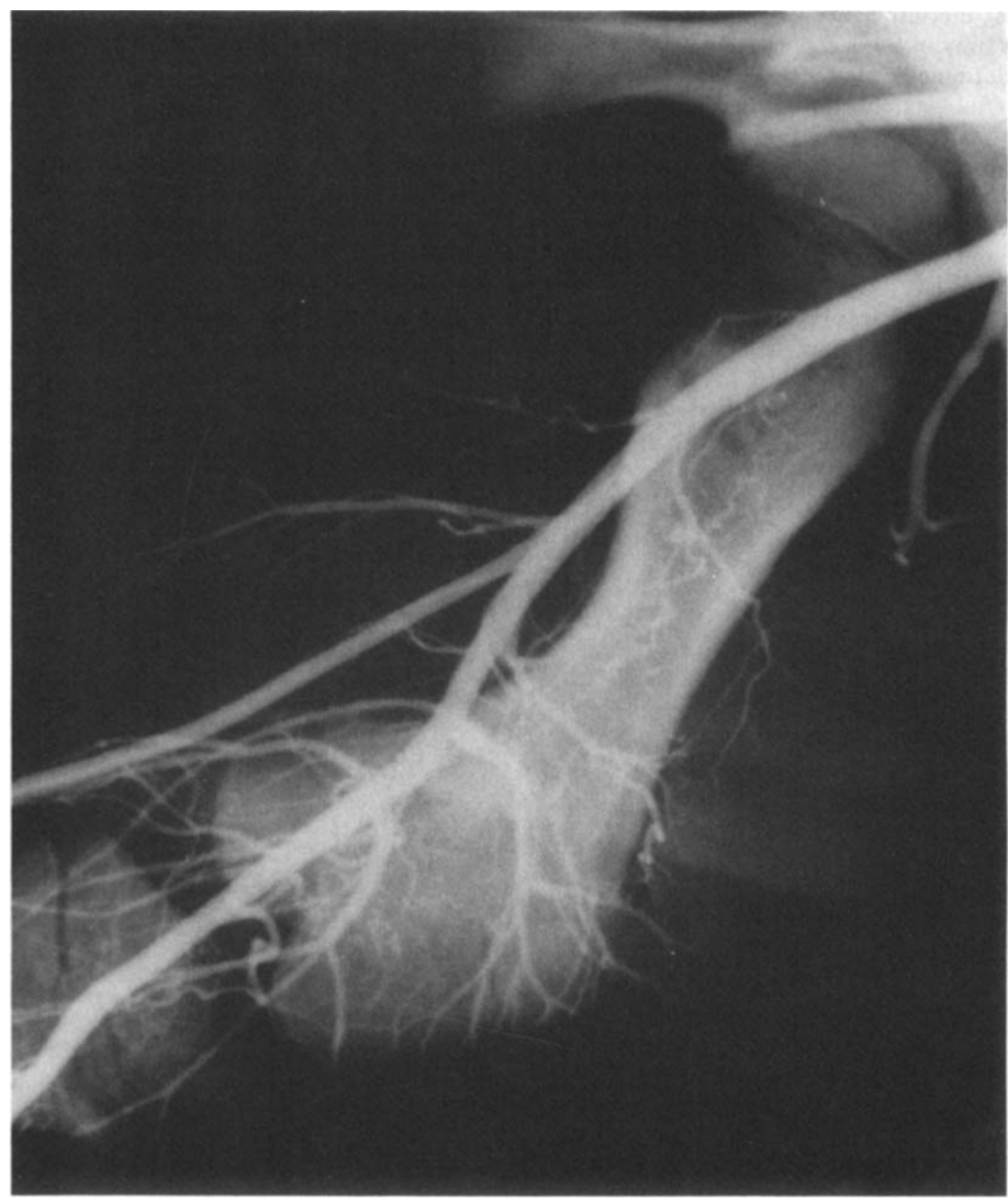

Figure 3B. Angiogram 10 days after implantation. The stent related artery is patent without signs of intraluminal defects. 
Starting the day of the procedure animals 1 and 2 received calciparin 25,000 IU subcutaneously daily until acenocoumarol had prolonged the prothrombin time three-fold. Aspirin $100 \mathrm{ml} / 24 \mathrm{~h}$ intravenously was also added. The other animals received only $100 \mathrm{mg}$ of aspirin in one daily oral dose. After 6 days (animals 1 and 2; 8 stents), 8 days (animals $3-5 ; 6$ stents) and 10 days (animal 6; 4 stents), the animals were again anesthetized, and angiography of the stent-related arteries was performed. Immediately thereafter the stent-containing arterial segments were dissected free, perfused in vivo with saline (perfusion pressure $75 \mathrm{mmHg}$ ) and removed. Thereafter the animals were sacrificed with an overdose of pentobarbitone sodium. The stent-containing arterial segments were placed in buffered glutaraldehyde for subsequent electron microscopy.

Electron Microscopy. After fixation in $4 \%$ formaldehyde and $1 \%$ glutaraldehyde in $0.1 \mathrm{M}$ caco- dylate buffer ( $\mathrm{pH} \mathrm{7.3)} \mathrm{for} \mathrm{at} \mathrm{least} 48$ hours, the stent containing arterial segments were washed in cacodylate buffer and divided lengthwise into two equal parts using a pair of fine scissors. One half of the stent underwent postfixation for 6 hours in $1 \%$ osmium tetroxide, and washing overnight in distilled water, and dehydration in graded ethanol and critical point drying with liquid $\mathrm{CO}_{2}$. This part of each vessel was mounted and sputtercoated with gold before examination in a scanning electron microscope (Cambridge 180 steroscan, Cambridge, U.K.).

From the other half of each vessel the stent wires were removed and the tissue was prepared for light microscopy.

Hematologic Measurements. Before administration of the anticoagulants, at the end of the implantation procedure and again after 2 and 6 days of recovery, $10 \mathrm{~mL}$ arterial blood was collected in a syringe containing sodium citrate (final concen-

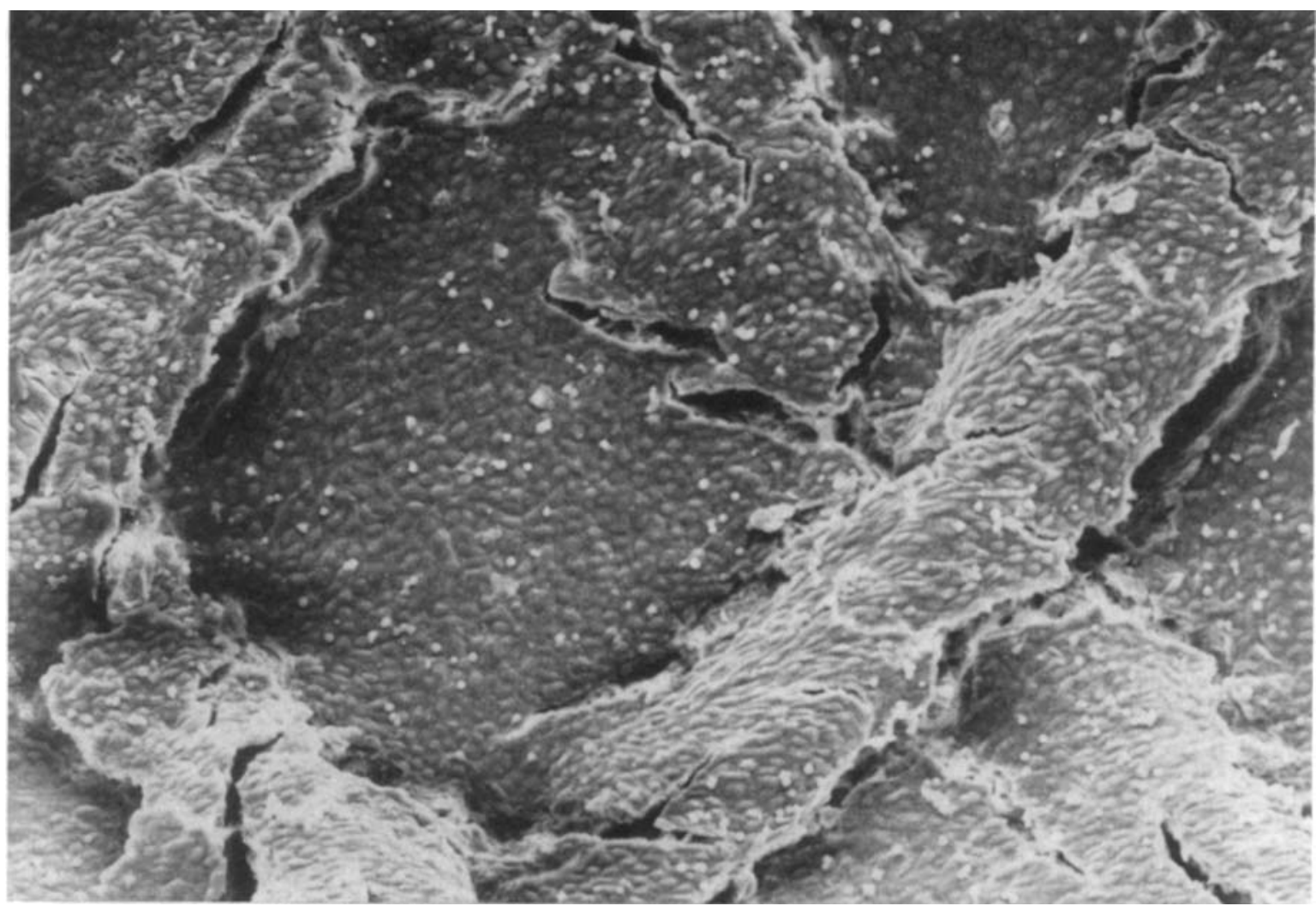

Figure 4. Scanning electron micrograph (magnification $1,250 \times$ ) of porcine femoral arterial segment 5 days after stent implantation. The wires are covered by a neointima with spindle shaped endothelial cells on the surface. Fissures in the endothelial layer are caused by this fixation procedure. 


\section{ENDOTHELIALIZATION OF INTRAVASCULAR STENTS}

tration $11 \mathrm{mM}$ ) for determination of the platelet count, recalcification time, and prothrombin time.

\section{Results}

In Vitro Endothelialization. Harvesting endothelium from human umbilical cord veins yielded approximately $2.10^{5}$ cells per vein $(10-15 \mathrm{~cm})$. After culturing these cells for 4 days about $10^{6}$ cells were available for seeding the stent. Incubation of these cells with the isolated stent for 2 hours and subsequent culturing resulted in an almost complete blanketing of the inner surface of the stent wires by flattened endothelial cells (Fig. 1).

Fluorescence staining of endothelial nuclei with Hoechst 33342 showed a uniform distribution of the cells on the stent wires (Fig. 2). Incubation of the stent mounted on the delivery catheter with isolated endothelium for 2 hours resulted in a similar endothelial lining. However, the inner surface proved to be covered for only approximately $50 \%$ after the stent had been released.

In Vivo Endothelialization in Porcine Femoral Arteries. All implanted stents remained patent during the period after implantation (6-10 days). Angiograms obtained at the end of the observation period showed no signs of stent-displacement, while stent-related intraluminal defects (considered to be caused by thrombus) could not be demonstrated in any of the implants (Fig. 3). Scanning electron microscopy showed that the stents were completely covered by an endothelial lining as early as 6 days after implantation (Fig. 4). No deposition of platelet aggregates or thrombus material was observed on the neointimal lining. Trans-

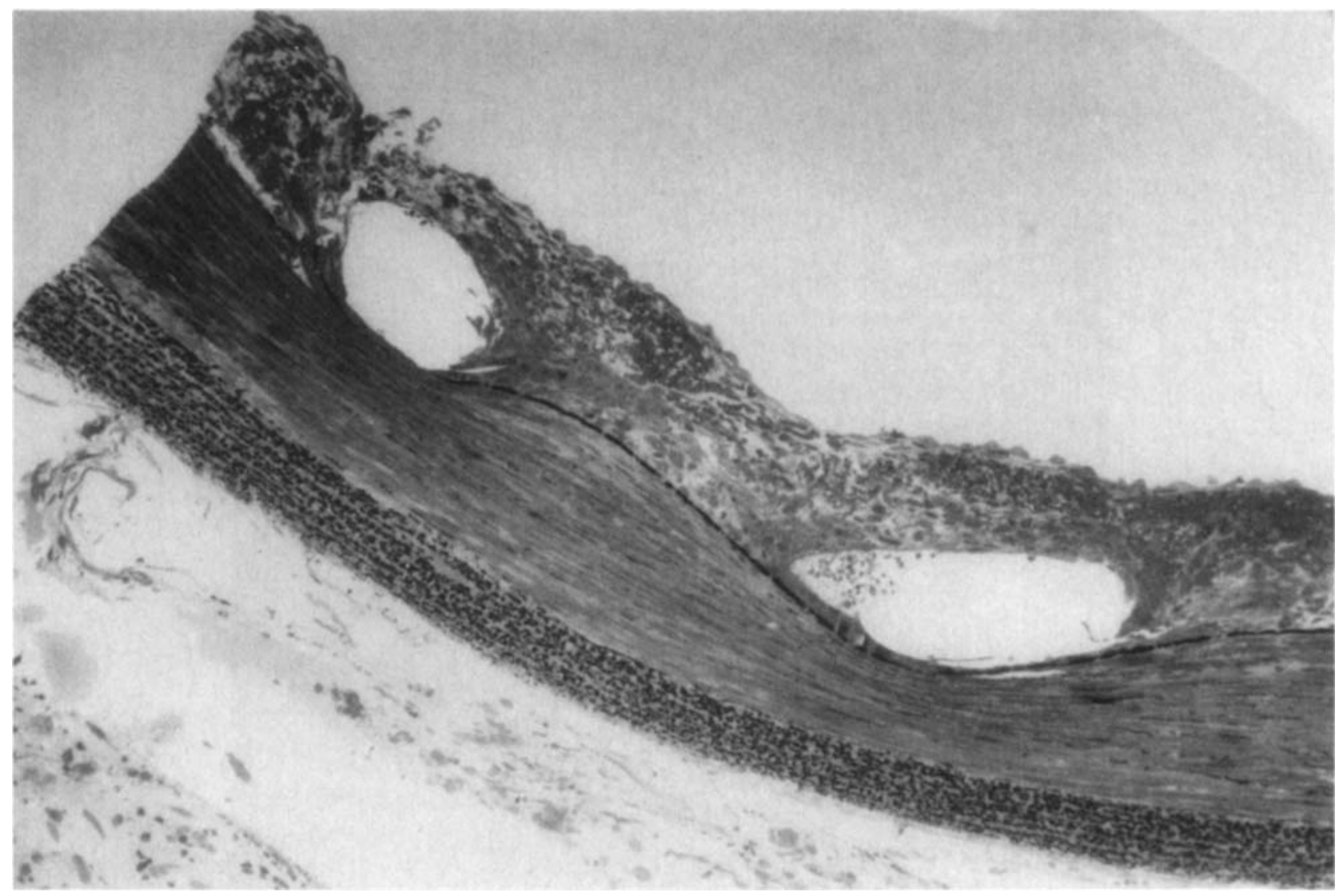

Figure 5A. Light microscopy of stented porcine femoral artery 3 days after implantation (magnification $190 \times$ ). The empty spaces correspond with the stent wires. At the site of the stent filaments the media is considerably compressed, while the internal elastic lamina is interrupted. 
mission microscopy showed that the stent filaments compressed the arterial media (Fig. 5A), with disruption of the internal elastic lamina (Figs.5A and 5B). A neointima of varying thickness covered the stent wires. While normal femo- ral arteries showed a thin intimal layer ( $5 \mu \mathrm{m}$ ), the median thickness of the stent covering neointima was $80 \mu \mathrm{m}$ (range 60-125 $\mu \mathrm{m}$ ). The neointima was covered with endothelial cells (Fig. 5C). In the neointima directly underneath the endothelium a

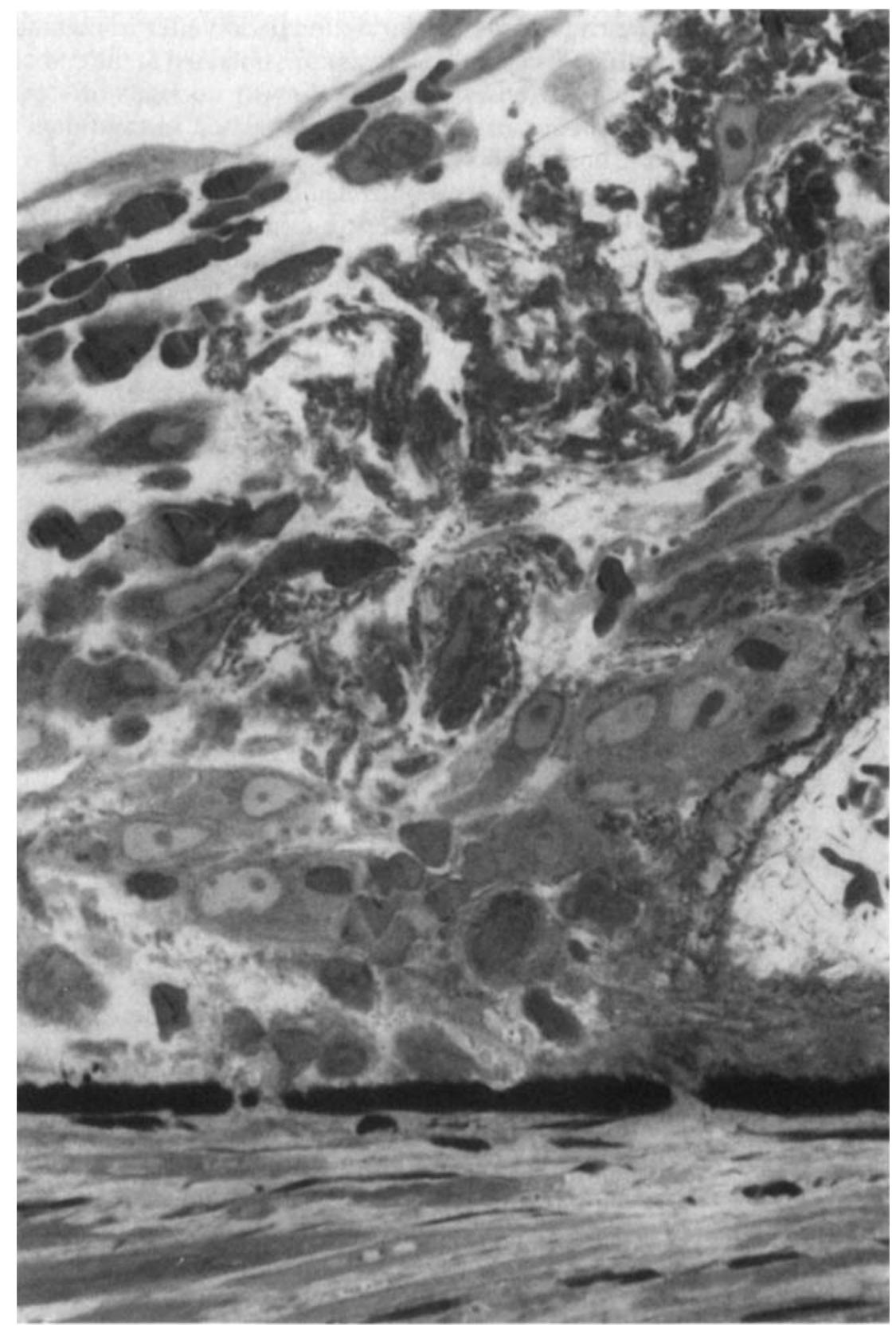

Figure 5B. (detail of 5A, magnification $510 \times$ ) In the neointima myofibrillar cells and macrophages are abundant. In the vicinity of this stent filament many trapped erythrocytes can be seen. 


\section{ENDOTHELIALIZATION OF INTRAVASCULAR STENTS}

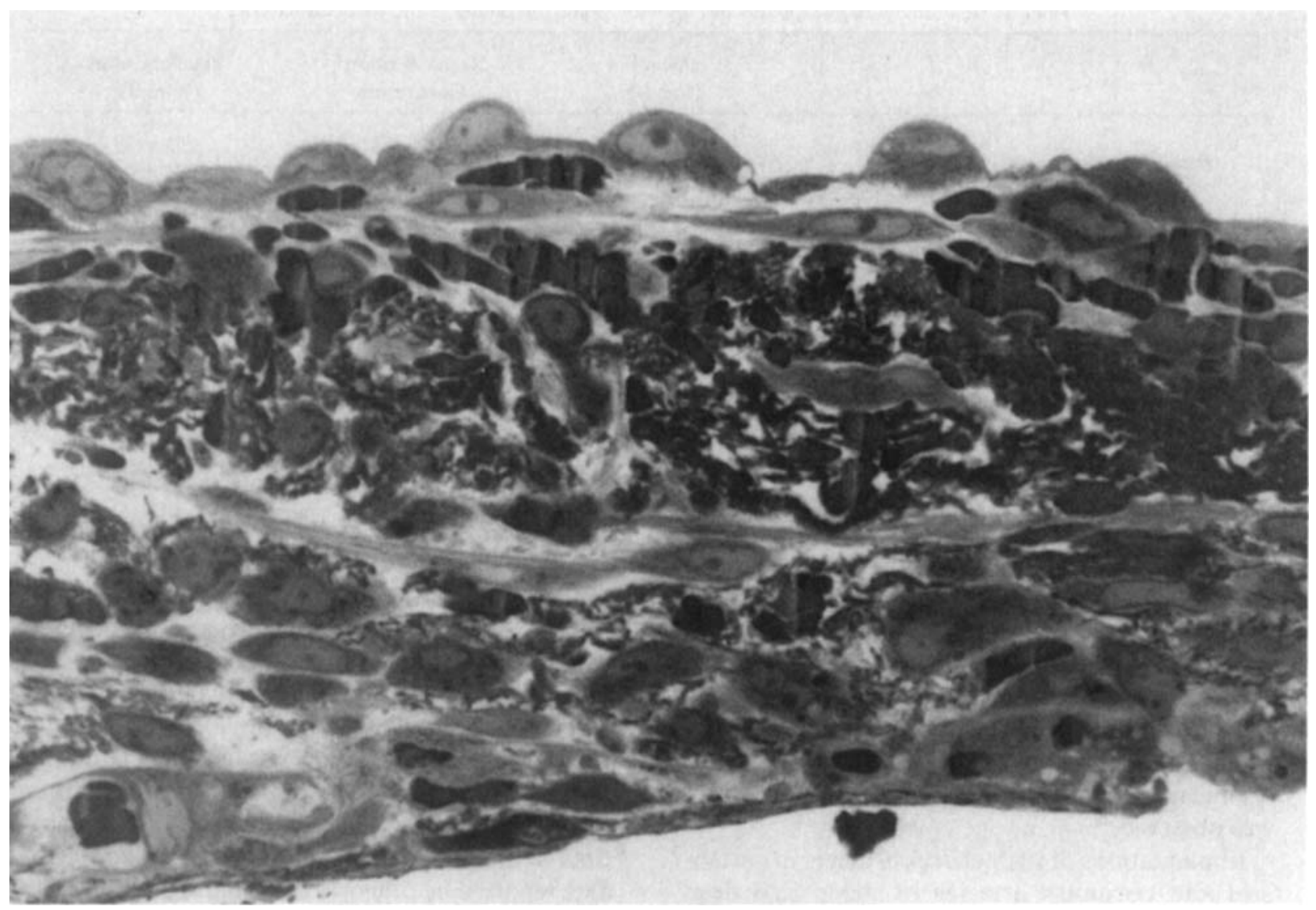

Figure 5C. (detail of 5A, magnification 510X) The neointima is covered by a continuous layer of endothelial cells. Between the endothelium and the stent many fibroblast-like cells can be seen, together with trapped erythrocytes and fibrous material.

mixture of fibers, trapped red blood cells and macrophage-type cells were present (Figs. 5B and 5C). Fibrous material, probably consisting of fibrin, occupied small areas between the stent filament and new intima. The presence of this fibrous material and the entrapped cells suggests that some deposition of thrombotic material might have occurred before the development of the neointima was completed.

No differences in ultrastructural appearance could be demonstrated between arterial segments that had been subjected to balloon angioplasty and those segments which were not dilated.

Hematological Data. The results of the hematological measurements are summarized in Table 1. During recovery prothrombin time and recalcification time were significantly prolonged in the animals receiving extensive anticoagulant therapy. In the animals receiving only aspirin, these values were normal again 2 days after implantation.

\section{Dissussion}

The application of percutaneous transluminal coronary angioplasty (PTCA) for the treatment of coronary artery disease has increased considerably in recent years. The initial success rate is high, ${ }^{10,11}$ with only a small incidence of acute or subacute occlusion at the site of angioplasty. ${ }^{12,13}$ However, restenosis several months after the procedure remains an unsolved problem with an incidence of $20 \%-40 \% .{ }^{14-16}$ The effect of pharmacological therapy on acute complications ${ }^{17-20}$ and late restenosis $^{20}$ is still unclear. The implantation of vascular endoprostheses after angioplasty to prevent these 
VAN DER GIESSEN, ET AL.

Table 1. Hematological Parameters of Pigs with Stents Implanted in the Femoral Arteries

\begin{tabular}{lcccc}
\hline & & $\begin{array}{c}\text { Prothrombin } \\
\text { Time (s) }\end{array}$ & $\begin{array}{c}\text { Recalcification } \\
\text { Time (min) }\end{array}$ & $\begin{array}{c}\text { Platelet Count } \\
\text { (mm-3) }\end{array}$ \\
\hline \multirow{3}{*}{ Baseline } & group 1 & $25 \pm 3$ & $2.5 \pm 0.3$ & $255 \pm 32$ \\
& group 2 & $25 \pm 1$ & $2.3 \pm 0.3$ & $305 \pm 44$ \\
End implantation & group 1 & $>180$ & $>15$ & $297 \pm 51$ \\
& group 2 & $30 \pm 2$ & $>15$ & $266 \pm 43$ \\
Day 2 & group 1 & $>180$ & $1.5 \pm 0.3$ & $261 \pm 7$ \\
& group 2 & $25 \pm 1$ & $>15$ & $314 \pm 52$ \\
Day 6 & group 1 & $>180$ & $1.6 \pm 0.3$ & $288 \pm 28$ \\
& group 2 & $24 \pm 1$ & $286 \pm 21$ \\
\hline
\end{tabular}

Group 1 (animals 1 and 2) received the extensive anticoagulant therapy; group 2 (animals 3-6) received only aspirin after implantation. All data have been presented as mean \pm SEM.

sequelae in patients with coronary atherosclerosis has proven feasible. ${ }^{21}$ Whether this technique actually reduces the incidence of restenosis is as yet unknown. Observations in a small number of patients show that the implantation of an endoprosthesis after balloon angioplasty causes an immediate slight further dilatation of the arterial segment. ${ }^{22}$ However, after 3 months a small but significant diffuse narrowing of the stented artery was observed..$^{23}$

Implantations of such endoprostheses in peripheral and coronary arteries in sheep and dogs showed early thrombotic complications $(<14$ days) in $20 \%-30 \%{ }^{6,7}$ This percentage can probably be reduced by avoiding some "thrombogenic" implantation parameters such as diameter mismatch between stent and receiving artery, stent margin at side-branch, low flow through the stented vessel and administration of low doses of aspirin $(5 \mathrm{mg} / \mathrm{kg})$ after implantation as in the present study. In vascular surgery comparable problems are encountered. Proposed solutions by this discipline comprise the design of nonthrombogenic vascular grafts, or seeding the graft surface with autologous endothelial cells. Cell-seeding might be the better solution, as this provides an active antithrombotic graft surface. ${ }^{24}$ Metal-alloy vascular endoprostheses currently available share the advantage, contrary to polymer surface vascular grafts, of macroporosity, covering up to $20 \%$ of the vascular surface area. This will allow earlier covering of the stent filaments with native endothelium. Endothelial covering was reported after 10 days to 8 weeks dependent upon the species, type of stent, size of receiving vessel and whether or not atherosclerotic lesions were present. ${ }^{3-6,25-27}$ In the present study it was shown that stents placed in porcine femoral arteries were already covered with neointima after 6 days. This faster rate of neointimal generation may be related to age and species of the animals. ${ }^{28}$ Prior balloon angioplasty, which has been shown to cause effective endothelial denudation in the same species, ${ }^{29}$ did not seem to delay this process. The thickness of the neointima in the present study $(80 \mu \mathrm{m})$ is comparable to data reported by others in the same species 8 weeks after implantation. ${ }^{25}$ Data reported for dog implantations seem more variable. After 1 to 3 weeks mean neointimal thicknesses of 80 to $300 \mu \mathrm{m}$ have been reported. ${ }^{6,26,27}$ After $6-12$ months these values were $270-450 \mu \mathrm{m} .^{7,27}$ Although one should be cautious in comparing results obtained in different species with different types of stents, and while most authors do not specify their measurements, the conclusion seems justified that neointimal thickening progresses gradually.

In man endothelial covering of vascular prothesis occurs much slower than in the pig. ${ }^{28}$ Accordingly the prosthesis is subjected to prothrombotic forces for a longer duration. This might imply the need for chronic antithrombotic treatment or other alternatives. Cell-seeding the stents might be that alternative. In the present study one of the clinically most relevant stents can be covered by endothelial cells in vitro, after relatively simple and nontime consuming measures. Scanning electron microscopy shows that the endothelial cells are flattened with close cell-to-cell contact. 


\section{ENDOTHELIALIZATION OF INTRAVASCULAR STENTS}

Whether these cells remain attached to the stent after intra-arterial placement depends upon the shear resistance, which has to be studied in further experiments. Furthermore it has to be established whether the cells remain viable and metabolically active, considering the dependence of the cells on endothelial cell growth factor. This dependence might be related to cell density in culture, but more data are needed to establish this. The use of autologous endothelial cell suspensions harvested from subcutaneous fat biopsies, avoids the need for tissue typing and the risk of cell rejection.

In conclusion, our study showed an early timespan wherein endovascular stents were covered by a neointima. Present data suggest that stents are at risk for partial or complete thrombotic occlusion during at least the first 6 days after implantation. Cell-seeding of the stent filaments, to obtain an active antithrombotic stent surface, seems an attractive method to reduce this risk. In vitro experiments demonstrated that stents can be covered by a substantial number of endothelial cells within hours. These data strongly suggest further in vivo experiments to investigate whether this approach may contribute to the solution of a major problem in current cardiologic interventions.

\section{References}

1. Dotter CT. Transluminally placed coil springs and arterial tube grafts: Long-term patency in the canine popliteal artery. Invest Radiol 1969; 4:329-332.

2. Dotter CT, Buschmann RW, McKinney MK, Rösch J. Transluminal expandable nitinol coil stent grafting: Preliminary report. Radiology 1983; 147:261-263.

3. Maass $D$, Zollikofer CL, Largiadèr F, Senning A. Radiological follow-up of transluminally inserted vascular endoprostheses: An experimental study using expanding spirals. Radiology 1984; 157:659-663.

4. Palmaz JC, Sibbitt RR, Tio FO, Reuter SR, Peters JE, Garcia F. Expandable intraluminal vascular graft: A feasibility study. Surgery 1986; 99:199-205.

5. Rollins N, Wright KC, Charnsangavej C, Wallace $S$, Gianturco C. Self-expanding metallic stents: preliminary evaluation in an atherosclerotic model. Radiology 1987 ; 163:739-742.

6. Rousseau H, Puel J, Joffre F, Sigwart U, Duboucher C, Imbert C, Knight C, Kropf L, Wallsten H. Self-exapanding endovascular prosthesis: An experimantal study. Radiology $1987 ; 164: 709-714$.

7. Sigwart U, Puel J, Mirkovitch V, Joffre F, Kappenberger L. Intravascular stents to prevent occlusion and restenosis after transluminal angioplasty. N Engl J Med 1987; 316:701-706.
8. Jaffe EA, Nachman RL, Becker CG, Minick CR. Culture of human endothelial cells derived from umbilical veins. J Clin Invest 1973; 52:2745-2756.

9. Van Hinsbergh VWM, Havekes L, Emeis JJ, Van Corven E, Scheffer M. Low-density lipoprotein metabolism by endothelial cells from human umbilical cord arteries and veins. Arteriosclerosis 1983; 3:547-559.

10. Anderson HV, Roubin GS, Leimgruber PP, Douglas JS King SB, Gr̈untzig AR. Primary angiographic success rates of percutaneous transluminally angioplasty. Am $\mathrm{J}$ Cardiol 1985; 56:712-717.

11. Myler RK, Topol EJ, Shaw RE, Stertzer SH, Clark DA, Fishman J, Murphy MC. Multiple vessel coronary angioplasty, classification, results and patterns of restenosis in 494 consecutive patients. Cath Cardiovase Diag 1987; 13:1-15.

12. Bredlau CE, Roubin ES, Leimgruber PP, Douglas JS, King SB, Grüntzig AR. In-hospital morbidity and mortality in patients undergoing elective coronary angioplasty. Circulation 1985; 72:1044-1052.

13. Simpfendorfer C, Belardi J, Bellamy G, Galan K, Franco I, Hollman J. Frequences, management and follow-up of patients with acute coronary occlusion after percutaneous transluminal angioplasty. Am J Cardiol 1987; 59:267269.

14. Grüntzig AR, King SB, Schlumpf M, Siegenthaler W Long-term follow-up after percutaneous transluminal coronary angioplasty. N Engl J Med 1987; 316:1127-1132.

15. Meier B, King SB, Grüntzig AR, Douglas JS, Hollman J, Ischinger T, Galan K, Tankersley R. Repeat coronary angioplasty. J Am Coll Cardiol 1984; 4:463-466.

16. Serruys PW, Luyten HE, Beatt KJ, Geuskens R, De Feyter PJ, van den Brand M, Reiber JHC, Ten Katen HJ, Van Es GA, Hugenholtz PG. Incidence of restenosis after successful coronary angioplasty: a time-related phenomenon. Cirulation 1988 (In press).

17. Bouraassa MG, Schwartz L, David PR, Aldridge H, Lesṕerance J, Bonan R, Henderson M, Salvatori V. The role of antiplatelet agents in reducing periprocedural coronary angioplasty (PTCA) complications. J Am Coll Cardiol 1988; $11(2)): 238 \mathrm{~A}$

18. Pow TK, Varricchione TR, Jacobs AK, Ruocco NA, Ryan TJ, Christelis EM, Faxon DP. Does pretreatment with heparin prevent abrupt closure following PTCA? J Am Coll Cardiol 1988; 11(2):238A.

19. Mufson L, Black A, Roubin G, Wilentz J, Mead S, McFarland K, Weintraub W, Douglas JS, King SB. A randomized trial of aspirin in PTCA: effect of high vs low dose aspiring on major complications and restenosis. J Am Coll Cardiol 1988; 11(2):236A.

20. Lembo NJ, Black AJ, Roubin GS, Mufson LH, Wilentz JR, Douglas JS, King SB. Does the addition of dipyridamole to aspirin decrease acute coronary angioplasy complications? The results of a prospective randomized clinical trial. J Am Coll Cardiol 1988; 11(2):237A

21. Blackshear JL, O'Callaghan WG, Califf RM. Medical approaches to prevention of restenosis after coronary angioplasty. J Am Coll Cardiol 1987; 9:834-848.

22. Serruys PW, Juilliere V, Bertrand ME, Puel J, Rickards AF, Sigwart U. Additional improvement of stenosis geometry in human coronary arteries by stenting after balloon dilatation: A quantitative angiographic study. Am J Cardiol 1988 (In Press).

23. Puel J, Juilliere $Y$, Bertrand ME, Rickards AF, Sigwart U, Serruys PW. Early and late assessment in stenosis geome- 


\section{VAN DER GIESSEN, ET AL.}

try after stenting of the human coronary arteries. Am J Cardiol 1988 (In Press)

24. Jarrell BE, Williams SK, Stokes G, Hubbard FA, Carabasi RA, Koolpe E, Greener D, Pratt K, Moritz MJ, Radomski J, Speicher L. Use of freshly isolated capillary endothelial cells for the immediate establishment of a monolayer on a vascular graft at surgery. Surgery 1986; 100:392-399.

25. Palmaz JC, Kopp DT, Mayashi H, Schatz RA, Hunter G, Tio FO, Garcia O, Alvarado R, Rees C, Thomas SC. Normal and stenotic renal arteries: experimental balloon-expandable intraluminal stenting. Radiology 1987; 164:705-708.

26. Schatz RA, Palmaz JC, Tio FO, Garcia F, Garcia O,
Reuter SR. Balloon-expandable intracoronary stents in the adult dog. Circulation 1987; 76:450-457.

27. Roubin GS, Robinson KA, King SB, Gianturco C, Black AJ, Brown JE, Siegel RJ, Douglas JS. Early and late results of intracoronary arterial stenting after coronary angioplasty in dogs. Circulation 1987; 76:891-87.

28. Sauvage LR, Berger KE, Wood SJ, Yates SG, Smith JC, Mansfield PB. Interspecies healing of porous arterial prostheses. Arch Surg 1974; 109:698-705.

29. Steele PM, Chesebro JH, Stanson AW, Holmes DR, Dewanjee MK, Badimon L, Fuster V. Balloon angioplasty. Natural history of the pathophysiological response to in jury in a pig model. Circ Res $1985 ; 57: 105-112$. 